because of the reduced workload and better staff ratios, as they are able to devote more time to commissioning.

With radical reforms of the NHS, the introduction of these healthcare professionals has the potential to improve health outcomes and free up GP time to focus on commissioning.

\section{Olumide Elegbe}

\section{REFERENCES}

1. Department of Health. Equity and excellence: liberating the NHS. London: Department of Health, 2010. http://www.dh.gov.uk/prod_consum_dh/groups/dh_di gitalassets/@dh/@en/@ps/documents/digitalasset/dh_1 17794.pdf (accessed 9 Aug 2010).

2. Gainsbury S. BMA leader urges GPs to hire NHS managers rather than private companies. Health Serv J 2010, 19 July: http://www.hsj.co.uk/news/primarycare/bma-leader-urges-gps-to-hire-nhs-managersrather-than-private-companies/5017376.article (accessed 9 Aug 2010).

3. Ford S. GP consortia will be a 'minority' interest. Health Serv J 2010, 21 July: http://www.hsi.co.uk/5017350.article?referrer=e2 (accessed 9 Aug 2010).

4. Gavin M. Physician assistants. Many general practitioners would welcome having physician assistants. BMJ 2002; 324(7339): 735. [Letter] http://www.bmj.com/cgi/content/extract/324/7339/735 (accessed 9 Aug 2010).

5. National Practitioner Programme 2006 - Recorded interview.

6. Buchan J, O'May F, Ball J. New role, new country: introducing US physician assistants to Scotland. Hum Resour Health 2007, 5: 13.

7. Frary T. A New Definition of 'Physician Assistant'. J Am Acad Physician Assist 1996; 9: 22-27.

8. Mittman DE, Cawley JF, Fenn WH. Physician Assistants in the United States. BMJ 2002; 325: 485-487.

9. Hutchinson L, Marks T, Pittilo M.The physician assistant: would the US model meet the needs of the NHS? BMJ 2001; 323: 1244-1247.

10. Abood A. Surgical Care Practitioners. BMJ Careers 2005; 26 Nov: 227.

11. White GL Jr, Davis AM. Physician Assistants as partners in physician directed care. Southern Med J 1999; 92: 956-960.

12. Wilson IB Landon BE, Hirschhom LR, et al. Quality of HIV Care provided by nurse practitioners, physician assistants and physicians. Ann Int Med 2005; 143(10): 729-737

13. Horrocks S, Anderson E, Salisbury C. Systematic review of whether nurse practitioners working in primary care can provide equivalent care to doctors. BMJ 2002; 324: can provide 823 .

14. Stewart A, Catanzaro. Can Physician Assistants be Effective in the UK? Clin Med 2005; 5: 344-348.

15. Chopra M, Munro S, Lavis JN, et al. Effects of policy options for human resources for health: an analysis of systematic reviews. Lancet 2008; 371: 668-674.

16. Ackermann RJ, Kemle KA.The effect of a physician assistant on the hospitalisation of nursing home residents. J Am Geriatr Soc 1998: 46; 610-614.

\title{
EDO - called to the dance!
}

The European Doctors Orchestra (EDO) came away from the vertiginous heights of last summer's achievement in Poznan where, with sublime impudence, the orchestra performed Beethoven's Ninth on 3 days' rehearsal, returning to London for its November concert in the Duke's Hall of the Royal Academy. The programme there also stretched it, but without that acute sense of striving for the greatest of all musical summits; in comparison, it was almost a 'pop' programme but one which showed off its strengths. The William Tell Overture was played with a lovely opening cello choir, an almost filigree delicacy of string playing in the overture's midsection, and a huge hurtling excitement in the coda. The orchestra moved next into Mahler's world of anguish and lost love, Lieder eines fahrenden Gesellen - by far the most difficult piece in the programme - and managed beautifully this sudden emotional switch, as evidenced by the tactful and sympathetic accompaniment of the baritone soloist John Ward. After that, it was glorious extroversion all the way, with EDO revelling in the technicolour travelogues of Scheherezade.

This summer, EDO went north to Edinburgh; we played to a packed house, in Greyfriars Kirk and between times were able to soak up the atmosphere of tourist tat and broad avenues and that wonderful weathered yellow sandstone. Some of us touched the hem of history by eating in the very restaurant where JK Rowling, then a single parent with a very young baby, would sit for hours over one cup of coffee as she worked on the first of the Harry Potter books.

As we played Hamish MacCunn's overture 'Land of Mountain and the Flood'; we were joined by the brilliant Josephine Robertson, a natural sciences student at Cambridge, as our soloist in Bruch's G Minor Violin Concerto, and our symphony was Dvorak's Eighth - on which we fell delightedly as one would an old friend. The work is a total joy, in contrast to the tragedy-inspired music produced by so many of Dvorak's contemporaries. The great trumpet calls at the start of the last movement recall Raphael Kubelik's comment at a rehearsal: 'Gentlemen, in Bohemia the trumpets call not to battle but to the dance!'. And that, indeed, was where we were called - to a céilidh, in the hallowed halls of the Royal College of Physicians. For some it was the first taste of Haggis and for many more it was the first time on a Scottish country dance floor, persuaded by the driving rhythms of an excellent band. We scrambled round the floor in the Gay Gordons, the Eightsome Reel, the Dashing White Sergeant, and many others, with hosts of willing hands pushing and pulling us through their snaking intricacies - after which any residual social ice was well and truly cracked!

And next? We play, again in the Duke's Hall in November. Our programme is something of a departure in that it is entirely English ... Elgar Cockaigne, Walton Viola Concerto, and Vaughan Williams 'London Symphony': 21st November, at $3.00 \mathrm{pm}$. We will be supporting Save the Children, and hope to see you there.

\section{Michael Lasserson}

DOI: 10.3399/bjgp10X515610 